\title{
Investigating stock structure and trophic relationships among island-associated dolphins in the oceanic waters of the North Atlantic using fatty acid and stable isotope analyses
}

\author{
Sophie Quérouil ${ }^{1,2^{*}}$, Jeremy Kiszka ${ }^{3}$, Ana Rita Cordeiro ${ }^{1,4}$, Irma Cascão ${ }^{1}$, Luís Freitas ${ }^{5,6}$, Ana \\ Dinis $^{5,6}$, Filipe Alves ${ }^{5,6}$, Ricardo Serrão $\operatorname{Santos}^{1} \&$ Narcisa M. Bandarra ${ }^{4}$ \\ ${ }^{1}$ Centre of IMAR of the University of the Azores / Department of Oceanography and Fisheries and LARSyS - \\ Associated Laboratory, 9901-862 Horta, Azores, Portugal. \\ ${ }^{2}$ Institut des Sciences de l'Evolution de Montpellier (ISE-M), IRD-UMR226, Université Montpellier 2, CC063, Place \\ Eugène Bataillon, 34095 Montpellier Cedex 5, France. \\ ${ }^{3}$ Marine Sciences Program, Department of Biological Sciences, Florida International University, 3000 NE 151 st, \\ North Miami, Florida 33181, USA. \\ ${ }^{4}$ IPMA, Instituto de Investigação do Mar e da Atmosfera, Avenida Brasília, 1449-006 Lisboa, Portugal. \\ ${ }_{6}^{5}$ Museu da Baleia da Madeira - Rua da Pedra d'Eira, 9200-031 Caniçal, Madeira, Portugal. \\ ${ }^{6}$ CIMAR/CIIMAR - Centre of Interdisciplinary Marine and Environmental Research, University of Porto, 4050-123, \\ Portugal. \\ * Corresponding author: sophie.querouil@ird.fr, Institut des Sciences de l'Evolution de Montpellier (ISE-M), IRD- \\ UMR226, Université Montpellier 2, CC063, Place Eugène Bataillon, 34095 Montpellier Cedex 5, France. Tel: +33 4 \\ 67143480 / Fax: +33467143622.
}

Key Words: Fatty acids, stable isotopes, trophic relationships, stock structure, Delphinus delphis, Stenella frontalis, Azores, Madeira, North Atlantic Ocean.

\begin{abstract}
Short-beaked common dolphins (Delphinus delphis) and Atlantic spotted dolphins (Stenella frontalis) are the two most abundant cetacean species in the oceanic waters of Madeira and the Azores. They are of similar size, occur in similar habitats and are regularly observed in mixedspecies groups to forage together. Genetic analyses suggested that, within each species, dolphins ranging around both archipelagos belong to the same panmictic population. We tested the hypotheses that 1 - within each species, individuals from the two archipelagos belong to a single ecological stock; 2- between species, common and spotted dolphins have distinct trophic niches; using fatty acid (FA) and stable isotope (SI) analyses. Fatty acids and stable isotopes were analysed from 86 blubber and 150 skin samples of free-ranging dolphins, respectively. Sex-related differences were not significant, except for common dolphin FA profiles. In S. frontalis, FA and SI differences between archipelagos suggested that individuals belonged to different ecological stocks, despite the existence of gene flow between the two archipelagos. In D. delphis, differences were more pronounced, but it was not possible to distinguish between stock structure and a seasonal effect, due to differential sampling periods in the Azores and Madeira. Inter-specific comparisons were restricted to the Azores where all samples were collected during summer. Differences in FA proportions, noticeably for FA of dietary origin, as well as in nitrogen SI profiles, confirmed that both species feed on distinct resources. This study emphasizes the need for an integrated approach including both genetic and biochemical analyses for stock assessment, especially in wide-ranging marine top predators.
\end{abstract}




\section{Introduction}

Conservation of communities and ecosystems necessitates knowledge on community structure and ecological niches of species feeding at different trophic levels, as well as information on stock structure of the species involved. Cetaceans, which are large size and highly mobile top predators, adapt their temporal distribution according to a number of parameters such as physiography, prey availability and predator pressure (e.g. Cañadas et al. 2002; Heithaus and Dill 2002); therefore reducing competition between species by niche partitioning (i.e. differential use of habitat and feeding resources through space and time; Grinnell 1924; Pianka 1974; Roughgarden 1976). In the case of small delphinid communities, several phylogenetically-related species with similar morphological characteristics may be found in sympatry. Investigating niche partitioning within these communities requires that all niche dimensions (habitat, resources and temporal variations) be investigated (Praca and Gannier 2008; Kiszka et al. 2011; Praca et al. 2011). This is all the more difficult as small cetaceans are highly mobile, difficult to observe and to sample, and can form large populations occupying extensive oceanic areas. Evaluation of population structure and definition of management units are also delicate issues. There is no consensus on the definition of stocks, although it is generally agreed that they should constitute genetically and demographically distinct units ( $c f$. Wade and Angliss 1997).

The Portuguese archipelagos of the Azores and Madeira host more than 20 species of cetaceans (Gonçalves et al. 1996; Santos-Reis and Mathias 1996; Steiner et al. 2007), including at least eight species of Delphinidae. Two of these species are very abundant in both archipelagos: the shortbeaked common dolphin (Delphinus delphis) and the Atlantic spotted dolphin (Stenella frontalis), hereafter common and spotted dolphins, respectively. Sea surveys indicated that they were the two most frequently sighted cetacean species around the Azores (Silva et al. 2003) and Madeira (Freitas et al. 2004). The two species are phylogenetically close (Le Duc et al. 1999) and of similar size (Evans 1994; Perrin et al. 1994). Previous studies suggested that spotted dolphins feed higher in the trophic chain than common dolphins ( $c f$. Pauly et al. 1998). While spotted dolphins mostly feed on squids, small pelagic and demersal fishes (Perrin et al. 1994; Lopes et al. 2012), common dolphins' diet includes a high proportion of mesopelagic fishes, particularly in the oceanic waters of the NE Atlantic (Pauly et al. 1998; Pusineri et al. 2007). In the neritic waters off west European coasts, common dolphins feed on taxonomically distinct species, with a preference for schooling preys (especially Clupeidae) of high energy content (Silva 1999; Meynier et al. 2008).

In the Azores, common dolphins are present all year round, while spotted dolphins are present only during summer months (Quérouil et al. 2008). In Madeira, common dolphins are mostly present in winter and spring, and spotted dolphins in summer and autumn, with very little overlap (Freitas et al. 2004). In the Azores, both species occasionally join and feed on the same schooling fishes, forming mixed-species associations (Quérouil et al. 2008). Common and spotted dolphins present some degree of spatial segregation in relation to habitat features. In the Azores and Madeira, common dolphins tend to prefer more coastal waters, while spotted dolphins tend to prefer deeper offshore waters (Silva et al. 2003; Freitas et al. 2004), even though the two species exploit largely overlapping habitats (Quérouil et al. 2008). Recent genetic data suggested that spotted and common dolphins ranging in the Azores and Madeira belong to the same populations (Quérouil et al. 2010a). However, the important distance $(\sim 900 \mathrm{~km})$ between the two archipelagos suggests the potential for finer scale population structure. Actually, genetic data alone are insufficient to evaluate stock structure, because low dispersal between demographically distinct populations may prevent genetic differentiation, especially in large populations (Wade and Angliss 1997).

In order to infer trophic niche partitioning, direct identification of prey during feeding events can only be performed opportunistically, and is limited to epipelagic schooling fish hunted collectively, during daytime, and close to the surface. In the Azores and Madeira, consumption of blue jack mackerel (Trachurus picturatus) and chub mackerel (Scomber japonicus) was frequently observed (Dinis et al. 2008). Consumption of other small pelagic fish, such as Atlantic mackerel 
(Scomber scombrus), European pilchard (Sardina pilchardus) and sardine (Sardinella sp.), was also recorded. (Dinis et al. 2008). In these oceanic archipelagos, diet inference based on stomach contents is not feasible due to the scarcity of incidental catches and strandings. Thus, indirect methods must be used, such as biochemical analysis of blubber fatty acids (e.g. Iverson et al. 2004) or stable isotope analyses (e.g. Lesage et al. 2001; Kiszka et al. 2010a). These indirect approaches are traditionally used for stranded or by-caught specimens, but can also be applied to live animals using a small sample of blubber or skin collected by biopsy darting (Hooker et al. 2001; Arnould et al. 2005; Kiszka et al. 2011).

The analysis of blubber fatty acid (FA) signatures has proven useful to detect intra- and interspecific variations in diet and elucidate foraging patterns in several marine mammal species (e.g. Borobia et al. 1995; Smith et al. 1996; Iverson et al. 1997a, b; Falk-Petersen et al. 2004). Interindividual differences in FA profiles may reflect differences in diet or metabolism (Newland et al. 2009). They are influenced by intrinsic factors such as age, sex, reproductive status, and body condition, and reflect food intake over the past few months (e.g. Samuel and Worthy 2004; Strandberg et al. 2008). At the intra-specific level, regional differences in FA signatures are frequently observed and may be used to detect stock structure of marine mammals (e.g. Iverson et al. 1997b; Brown et al. 1999; Thiemann et al. 2008). Intra-specific variations seem to depend mainly on extrinsic factors such as local variations in water temperatures, lipid composition of the plankton and prey availability. Inter-specific variations in FA profiles are influenced by the species diets and by environmental features, but also by metabolic pathways and phylogenetic history (Borobia et al. 1995). Thus, they can only be used to infer diet differences between phylogenetically related species (Smith and Worthy 2006; Thiemann et al. 2008). Some FA can be modified before deposition in the adipose tissue or endogenously produced by de novo synthesis, and may not adequately reflect prey consumption (Kirsch et al. 2000; Olsen and Grahl-Nielsen 2003; Iverson et al. 2004; Budge et al. 2006). The FA that cannot be synthesized de novo, such as some odd and branched saturated fatty acids, as well as some polyunsaturated fatty acids (PUFA), that are exclusively obtained from exogenous sources (i.e. essential FA) are considered as good trophic markers (Nakamura and Nara 2003, Falk-Petersen et al. 2004).

Naturally occurring nitrogen and carbon stable isotopes (SI) provide alternative information to better understand marine mammals feeding ecology (Hobson and Welch 1992; Abend and Smith 1997; Das et al. 2003) as well as stock structure and habitat partitioning (Smith et al. 1996; Borrell et al. 2006). Various tissues with varying temporal resolution may be used for SI analyses, including skin (Kiszka et al. 2010b, 2011). The carbon and nitrogen isotope ratios $(13 \mathrm{C} / 12 \mathrm{C}$ and $15 \mathrm{~N} / 14 \mathrm{~N}$, expressed hereafter as $\delta^{13} \mathrm{C}$ and $\delta^{15} \mathrm{~N}$ ) of a consumer reflect those of its diet, with a slight retention of the heavier isotope and excretion of the lighter one. Isotopic enrichment is high for nitrogen, which is therefore a good marker of trophic level; while it is low for carbon, which better reflects the geographic origin of food resources.

It is noteworthy that cetacean blubber is organized in three layers that have different functional roles and different FA compositions and turn-over rates (Olsen and Grahl-Nielsen 2003; Samuel and Worthy 2004; Smith and Worthy 2006; Strandberg et al. 2008). The outer layer operates mostly as an insulator. Its composition is rather stable overtime and tends to be consistent between individuals. The middle layer is a storage site that varies in thickness according to food consumption, but does not vary much in composition. The inner layer serves mostly for short-term energy storage and reflects recent food intake. Its turn-over rate has not yet been estimated, but it is presumably in the order of magnitude of a few months ( $c f$. Samuel and Worthy 2004). As for SI, the estimated time required for cell migration, from the basal lamina to the outermost surface of the skin, is at least two months (70-75 days in T. truncatus, Hicks et al. 1985; St Aubin et al. 1990). Therefore, blubber FA and SI analyses provide information on the feeding ecology of dolphins during a period of a few months preceding sampling. 
In order to better understand stock structure and trophic relationships among common and spotted dolphins around the Azores and Madeira, we examined differences in FA and SI profiles between sexes, archipelagos and species. We hypothesized that 1 - individuals from the two archipelagos belong to a single stock within each species (as suggested by genetic analyses), thus would have similar FA and SI profiles; 2- common and spotted dolphins have distinct trophic niches that would be reflected by distinct FA and SI profiles.

\section{Material and methods}

\section{Sample collection}

Biopsy samples were collected in the Portuguese archipelagos of the Azores and Madeira (Fig. 1). In the archipelago of the Azores, samples were obtained in the central group of islands around $38.5^{\circ} \mathrm{N}$ and $028.6^{\circ} \mathrm{W}$ (Faial, Pico, São Jorge and seamounts situated $40 \mathrm{~km}$ south of Faial; $c f$. Quérouil et al. 2010a for more information). Sampling was restricted to the summer months, due to adverse meteorological conditions preventing fieldwork in winter. This was also the season when both species were present simultaneously in the Azores. In the archipelago of Madeira, samples were collected along the eastern and southern coast of the main island, close to $32.7^{\circ} \mathrm{N}$ and $016.7^{\circ} \mathrm{W}$. Samples were obtained at different seasons for common and spotted dolphins, during their respective periods of occurrence.

Skin and blubber samples were collected on live dolphins using a biopsy darting system (125-lb Barnett crossbow, with arrows and darts specially designed for small cetaceans by F. Larsen, CetaDart; Mathews et al. 1988). Samples were $0.5 \mathrm{~cm}$ in diameter and about $1.5 \mathrm{~cm}$ in depth. Care was taken to target the flanks of the animals, immediately below and behind the dorsal fin. At sea, samples were stored on ice for a period of one to eight hours. The skin was then separated from the blubber. Blubber samples were stored at $-80^{\circ} \mathrm{C}$ and skin samples were stored in $90 \%$ ethanol at $20^{\circ} \mathrm{C}$.

\section{Determination of sex and detection of repeated samples}

Genetic analyses were conducted on skin samples at the INETI, Lisbon, Portugal. They aimed at determining the sex of sampled individuals (molecular sexing) and ensuring that all the samples came from different individuals (genotyping). Molecular sexing was achieved by co-amplification of a short fragment of the male-specific SRY gene (CSY) and a microsatellite fragment used as a PCR control for positive identification of females (GATA028). Genotyping was based on 12-14 highly polymorphic microsatellite loci. Methodological details are given in Quérouil et al. (2010a). Samples with identical genotypes were assumed to come from the same individual and duplicate samples removed from the dataset. Finally, 86 blubber samples and 150 skin samples from distinct physically mature individuals were selected, taking care to equilibrate the number of samples between species, archipelagos and sexes (Table 1). However, sex ratio was highly skewed in favour of males in the biopsy samples from Madeira ( $c f$. Quérouil et al. 2010b), and very few female samples were available for this archipelago.

\section{Fatty acid analyses}

The small size of biopsy samples did not allow analysing each blubber layer separately, as usually done for samples from stranded specimens. Samples were checked for presence of all fat layers by comparison to reference samples that reached the muscle, where small veins were visible. Samples suspected to be lacking the inner layer were discarded. Samples were lyophilized prior to analyses. Lipids were not extracted due to the small size of the samples. Fatty acid methyl esters (FAME) were prepared through base-catalyzed trans-esterification, following Park et al. (2001) and Kramer et al. (2002). FAME analyses were performed in a Varian Star $3800 \mathrm{Cx}$ gas chromatograph, equipped with an auto-sampler and fitted with a flame ionization detector at $250^{\circ} \mathrm{C}$. The separation 
was achieved using a capillary column Omegawax $(30 \mathrm{~m}$ length, $0.25 \mathrm{~mm}$ internal diameter and $0.25 \mu \mathrm{m}$ film thickness) from Sigma-Aldrich, Inc. After holding at $180^{\circ} \mathrm{C}$ for $5 \mathrm{~min}$, the temperature was raised to $220^{\circ} \mathrm{C}$ at $4^{\circ} \mathrm{C} / \mathrm{min}$, and maintained at $220^{\circ} \mathrm{C}$ for $25 \mathrm{~min}$, with the injector at $250^{\circ} \mathrm{C}$. The split ratio was $100: 1$. Peak identification was made by comparison of retention times with the FA methyl ester standards from Sigma-Aldrich, Inc. In each series of samples, a blank was used to confirm the absence of phthalates or possible co-eluates after GC injection. The methodology was validated using certified reference material (CRM 164-anhydrous milk fat) from the Community Bureau of Reference in Brussels, Belgium.

\section{Stable isotope analyses}

Stable isotope analyses were performed on skin samples stored in ethanol, which was the most suitable preservative that could be used due to logistical constraints. Ethanol storage may have variable and organism-dependent effects on SI signatures, generally higher on $\delta^{13} \mathrm{C}$ values than on $\delta^{15} \mathrm{~N}$ values (Kaehler \& Pakhomov, 2001). It does not affect SI signatures in freshwater zooplankton and benthic macroinvertebrates (Syväranta et al. 2008), bird eggs, blood and muscle (Hobson et al. 1997; Gloutney \& Hobson, 1998). An increase in $\delta^{13} \mathrm{C}$ values is generally considered to be caused by the presence of lipids in the sample. However, as lipids are depleted in $\delta^{13} \mathrm{C}$, they must be extracted to avoid a bias in the isotopic signature of $\delta^{13} \mathrm{C}$ (De Niro \& Epstein, 1978; Tieszen et al. 1983). This process likely cancels any potential effect of storage in ethanol.

The ethanol was evaporated at $45^{\circ} \mathrm{C}$ over $48 \mathrm{~h}$ and the samples were ground and freeze-dried (Hobson et al. 1997). Lipid extraction was done by shaking ( $1 \mathrm{~h}$ at room temperature) in cyclohexane (C6H12), and subsequent centrifugation prior to analysis. After drying, small subsamples $(0.35$ to $0.45 \mathrm{mg}+0.001 \mathrm{mg})$ were prepared for analysis. Stable isotope measurements were performed with a continuous-flow isotope-ratio mass spectrometer (Delta V Advantage, Thermo Scientific, Germany) coupled to an elemental analyser (Flash EA1112 Thermo Scientific, Italy). Results were expressed in $\delta$ notation relative to PeeDee Belemnite and atmospheric $\mathrm{N}_{2}$ for $\delta^{13} \mathrm{C}$ and $\delta^{15} \mathrm{~N}$, respectively, according to the equation:

$$
\delta X=\left[\frac{R_{\text {sample }}}{R_{\text {stan dard }}}-1\right] \times 1000
$$

where $\mathrm{X}$ is ${ }^{13} \mathrm{C}$ or ${ }^{15} \mathrm{~N}$ and $\mathrm{R}$ is the isotope ratio ${ }^{13} \mathrm{C} /{ }^{12} \mathrm{C}$ or ${ }^{15} \mathrm{~N} /{ }^{14} \mathrm{~N}$, respectively. Replicate measurements of internal laboratory standards (acetanilide) indicated that measurement errors were $<0.1 \%$ for $\delta^{13} \mathrm{C}$ and $\delta^{15} \mathrm{~N}$. Percent $\mathrm{C}$ and $\mathrm{N}$ elemental composition of tissues were obtained using the elemental analyzer. Sample $\mathrm{C}: \mathrm{N}$ ratios were calculated, indicating good lipid removal efficiency when $<4$.

\section{Statistical analyses}

Fatty acid proportions were calculated individually for each FA, as well as the total amount of saturated (SFA), monounsaturated (MUFA) and polyunsaturated (PUFA) fatty acids. The total amounts of n-3 or n-6 PUFA were also calculated as they are considered as reliable indicators of food intake ( $c f$. Falk-Petersen et al. 2004).

Fatty acids present in trace amounts $(<0.5 \%)$ were excluded from the analyses, since the precision of their determination was low ( $c f$. Dahl et al. 2000; Walton and Pomeroy 2003). FA proportions (in percentage of total FAMEs) and summary variables (total SFA, MUFA, PUFA, n-3 and n-6 FA) were calculated for each sample and averaged over sexes and archipelagos. FA proportions were normalized using a logarithmic transformation in order to level out differences between FA present in large and small amounts ( $c f$. Falk-Petersen et al. 2004). Multivariate analyses were used to compare FA proportions between sexes, archipelagos and species. Due to the non-independence between seasonality and the geographic origin of samples (given that D. delphis was only present in Madeira in winter, while all other samples were obtained in summer or autumn), intra- and 
inter-specific comparisons were performed separately. Within each species, FA proportions were compared between archipelagos. Inter-specific comparisons were restricted to the archipelago of the Azores, where all samples had been collected in summer. The main trends in blubber FA composition were identified by a Principal Component Analysis (PCA). Variations in global FA proportions between sexes, archipelagos and species were investigated by a Multiple Analysis of Variance (MANOVA). As for the summary variables, a two-way Analysis of Variance (ANOVA) was conducted. Differences in FA profiles were characterized by a discriminant function analysis, using the stepwise backward option to select the discriminatory variables.

Pairwise comparisons of $\delta^{13} \mathrm{C}$ and $\delta^{15} \mathrm{~N}$ values between sexes, archipelagos and species were performed using Mann-Whitney- $U$ tests, following the same scheme as above. All statistical analyses were performed with the package Statistica 6.1 for Windows (StatSoft Inc, USA), using a significance level of $\alpha=0.05$.

\section{Results}

\section{Fatty acids}

Forty-five FA were identified, among which 21 were present in proportions superior to $0.5 \%$ of total FA (accounting for $92-94 \%$ of total FA; Table 2). Inter-individual variability was high, but in all samples FA profiles were dominated by monounsaturated fatty acids (MUFA), followed by polyunsaturated fatty acids (PUFA) and saturated fatty acids (SFA).

In common dolphins, the first three principal components of the PCA accounted for $48.1 \%, 12.6 \%$ and $10.7 \%$ of the total variance, respectively. The scatterplot of the samples on the first two axes showed a continuum between the two archipelagos, and partial separation between sexes for the Azorean samples (Fig. 2). The MANOVA indicated a significant effect of archipelagos, sex and the interaction between archipelagos and sex on inter-individual variations in global FA proportions (Table 3). There was also a significant effect of archipelago on all summary variables, while the effect of sex was significant for $\Sigma$ PUFA only (Table 3). There was no effect of the interaction between archipelagos and sex on the summary variables. The discriminant analysis performed on samples grouped by sex and archipelagos identified a single FA, 18:3n-3 (alpha linolenic acid, ALA), as discriminatory variable between the four groups (Wilk's $\lambda=0.369, \mathrm{p}<$ 0.0001 ), and yielded high misclassification rates (mean of $27.3 \%$ for the whole data set). The discriminant analysis performed after pooling male and female samples by archipelago identified FA 18:3n-3 (ALA) and 20:4n-6 (araquidonic acid, AA) as discriminatory variables (Table 4), with misclassification rates of $13.6 \%$ for the Azores, $0 \%$ for Madeira, and $6.8 \%$ for the whole data set. In spotted dolphins, the first three principal components of the PCA accounted for $39.9 \%, 14.7 \%$ and $12.1 \%$ of the total variance, respectively. The scatterplot of the samples on the first two axes showed a continuum between the two archipelagos along the second axis (Fig. 3). The MANOVA indicated a significant effect of archipelagos on inter-individual variations in global FA proportions, but no effect of sex nor of the interaction between archipelagos and sex (Table 3). There was a significant effect of archipelagos on the total amount of n-6 FA, but no effect on other summary variables (Table 3). There was no effect of sex nor of the interaction between archipelagos and sex on the summary variables. As FA proportions were not influenced by sex, male and female samples were pooled within each archipelago. The discriminant analysis identified FA 20:1n-9, 20:4n-3 and 20:5n-3 (EPA) as discriminating variables between archipelagos (Table 4). The misclassification rates were 18.2\% for the Azores, $15.0 \%$ for Madeira, and $16.7 \%$ for the whole data set.

Comparison of FA profiles between common and spotted dolphins was restricted to the Azores. The first three principal components of the PCA accounted for $38.5 \%, 22.7 \%$ and $10.3 \%$ of the total variance, respectively. The scatterplot of the samples on the first two axes indicated that samples clustered by species, principally along the second axis (Fig. 4). The MANOVA indicated 
a significant effect of species on inter-individual variations in FA proportions, but no effect of sex nor of the interaction between species and sex (Table 3). There was a significant effect of species on all summary variables except $\Sigma$ SFA. There was no effect of sex on the summary variables, but there was an effect of the interaction between species and sex on $\Sigma$ PUFA and $\Sigma$ n-6 PUFA (Table 3 ). As FA proportions were not influenced by sex, male and female samples were pooled within each species. The discriminant analysis identified FA 14:0 isobr, 15:0, 18:1n-7, 18:2n-6 (LA) and 22:6n-3 (DHA) as discriminating variables between species (Table 4). All samples were correctly classified by the discriminant function.

\section{Stable isotopes}

Sex differences were tested within each species and archipelago, but no significant differences were detected (all pairwise comparisons, $\mathrm{p}>0.05$ ). In common dolphins, carbon and nitrogen isotope values were significantly different between the two archipelagos $\left(\delta^{13} \mathrm{C}: \mathrm{U}=422, \mathrm{p}=\right.$ $\left.0.0008 ; \delta^{15} \mathrm{~N}: \mathrm{U}=477, \mathrm{p}=0.005\right)$. In spotted dolphins, only carbon isotopes values significantly differed between the Azores and Madeira $\left(\delta^{13} \mathrm{C}: U=268, p=0.002 ; \delta^{15} \mathrm{~N}: U=499, p=0.926\right.$; Fig. 5).

Off the Azores, $\delta^{13} \mathrm{C}$ values were not statistically different between the two species $(\mathrm{U}=1182, \mathrm{p}=$ $0.846)$, but common and spotted dolphins had significantly different $\delta^{15} \mathrm{~N}$ signatures $(\mathrm{U}=880, \mathrm{p}=$ 0.02), with spotted dolphins having higher $\delta^{15} \mathrm{~N}$ values than common dolphins (Fig. 5).

\section{Discussion}

\section{General trends and inter-individual variations in FA and SI signatures}

Observed FA proportions were globally consistent with those reported for other cetacean species (Williams et al. 1987; Koopman et al. 1996; Iverson et al. 1997b; Guitart et al. 1999; Samuel and Worthy 2004), including biopsy samples of bottlenose dolphins from the Azores (Walton et al. 2007). In D. delphis, global FA composition was comparable to that previously reported for specimens of the Northeast Pacific (Smith and Worthy 2006), although MUFA tended to be less represented and PUFA more abundant in our study. For this species, isotopic values measured in our skin samples were similar to those observed in muscle samples from the Northeast Atlantic (Das et al. 2000). As for S. frontalis, it is the first time that information is provided on detailed FA composition and SI signatures.

In both species, inter-individual variability in FA profiles was high. It was probably influenced by intrinsic factors, such as age, sex (Koopman et al. 1996, 2003; Iverson et al. 1997b; Kirsch et al. 1998), reproductive status (Aguilar and Borrell 1990; Samuel and Worthy 2004) and nutritional state (Koopman et al. 2003). Even though care was taken to sample apparently healthy, large-size and presumably physically mature individuals, it was not possible to get precise information on the age and reproductive status of the animals.

Sex-related differences were observed in D. delphis FA profiles only. Differences in FA profiles between males and females have previously been reported in Pacific common dolphins (Smith and Worthy 2006). Stomach content analyses revealed significant foraging differences between sexes in common dolphins of the south-western Indian Ocean (Young and Cockcroft 1994), North Pacific Ocean (Chou et al. 1995) and Bay of Biscay (Meynier et al. 2008), and minor differences in common dolphins from the Portuguese continental waters (Silva 1999). Thus, it is possible that the sex-related differences we observed in D. delphis reflect diet differences between genders. Lack of significant differences between sexes in $S$. frontalis FA and SI signatures might be explained by the small number of female samples available for Madeira and lack of consideration of female reproductive status. However, differences are often slight and not significant in small delphinids (e.g. Kiszka et al. 2010a). 
It should be noted that, while methodological constraints on the FA analyses leading to simultaneous analysis of all blubber layers might have limited our ability to detect dietary differences that might be evident in the inner layer only ( $c f$. Koopman et al. 1996, 2003; Olsen and Grahl-Nielsen 2003), significant differences in FA profiles were indeed observed at the interindividual, intra- and inter-specific levels.

\section{Stock structure}

Results were consistent for the two biochemical markers, revealing differences in FA and SI profiles between archipelagos that were more pronounced in common than in spotted dolphins ( $c f$. summary Table 5). In D. delphis, global FA composition and all summary variables differed between archipelagos, and the discriminant analysis discriminated between the Azores and Madeira. Carbon and nitrogen isotopes were also significantly different. It was not possible to conclude that common dolphins from the Azores and Madeira have different feeding habits and belong to separate stocks, due to the non independence between sampling seasons and archipelagos. The sampling period is not always taken in consideration in studies where biochemical markers are used to assess stock structure. However, it is an important issue because of the existence of seasonal variations in water temperature, prey availability, prey composition, dolphin behaviour (migration) and nutritional condition (Samuel and Worthy 2004; Wheatley et al. 2007; Thiemann et al. 2008). We recommend that special efforts should be made to collect common dolphin samples in the Azores during winter, in order to differentiate seasonal effects from regional variations. It is noteworthy that, provided that the observed differences would represent temporal rather than geographic variations, the difference in nitrogen values would imply a seasonal shift in trophic level.

In $S$. frontalis, for which all samples had been collected during summer, differences between archipelagos were observed in global FA composition and for a single summary variable. The discriminant analysis allowed discriminating between archipelagos with a misclassification rate of one in six. Differences were significant for carbon isotopes, but not for nitrogen isotopes, indicating that individuals from the Azores and Madeira forage on different preys or in different habitats, at the same trophic level. These results suggest that spotted dolphins from the Azores and Madeira may be considered as distinct ecological stocks.

\section{Trophic relationships}

Trophic niche partitioning between species was only investigated in the Azores, where all samples were collected during summer ( $c f$. summary Table 5). We found significant differences in FA signatures and summary variables, including n-3 and n-6 PUFA. The discriminant analysis identified five FA that allowed discriminating perfectly between the two species. Among these, FA 15:0 and LA cannot be synthesised by mammalian species, and DHA is produced from EPA with a very limited conversion rate (less than $0.05 \%$ ). These three FA are therefore of dietary origin ( $c f$. Nakamura and Nara 2003; Smith and Worthy 2006; Wang et al. 2006). Even though the importance of the blubber as an insulator and a site of energy storage complicates the interpretation of blubber FA profiles in terms of diet (Kleivane et al. 1995; Samuel and Worthy 2004), the observed differences in FA profiles between common and spotted dolphins probably reflect differences in prey consumption. Our results suggest that common dolphins eat more pelagic fish and/or cephalopods (richer in PUFA, especially n-3 PUFA, Bandarra et al. 1997; Hooker et al. 2001; Phillips et al. 2002; Özyurt et al. 2006), while spotted dolphins eat more deep sea fish (richer in MUFA; Saito and Murata 1998).

Nitrogen isotope values were significantly higher in spotted than in common dolphins, confirming that the former feed at a higher trophic level. Lack of difference in carbon isotope values could indicate either superposition of foraging habitats between species or inadequacy of this tracer to discriminate between oceanic habitats (cf. Praca et al. 2011). 


\section{Conclusion}

As expected, differences in nitrogen isotopes and blubber FA profiles between common and spotted dolphins suggest that the two species feed on different preys and/or in different habitats. Inter-specific niche partitioning is reinforced by the spatio-temporal distribution of both species, which show temporal segregation in Madeira. The co-occurrence of both species in the Azores and the formation of poly-specific associations (Quérouil et al. 2008) are likely to be related to the temporary presence of abundant resource species (especially blue jack mackerels Trachurus picturatus), when the two predators co-occur (Clua and Grosvalet 2001).

While data are insufficient to infer whether the FA and SI differences observed in D. delphis imply that individuals from the two archipelagos belong to distinct stocks, the differences observed in $S$. frontalis suggest the existence of distinct ecological stocks in the Azores and Madeira. This finding was unexpected given that a recent genetic study had failed to uncover any population structure at the scale of the two archipelagos (Quérouil et al. 2010a). However, it has already been pointed out that genetic data alone are insufficient to define stock boundaries (Wade and Angliss 1997) Genetic analyses reflect population structure on the long term, above the individual timescale, while biochemical analyses provide short-term information, at the seasonal time-scale. Both types of data are therefore complementary. The present study emphasizes the need for an integrated approach including both evolutionary and ecological data for stock assessment and conservation issues.

\section{Acknowledgements}

Authors are very grateful to the Portuguese Foundation for Science and Technology (FCT) and the FEDER program for funding the GOLFINICHO project (POCI/BIA-BDE/61009/2004), S.Q.'s post-doctoral grants (IMAR/FCT- PDOC-006/2001-MoleGen and SFRH/BPD/19680/2004), A.R.C and I.C.'s investigation assistant grants (IMAR/FCT/GOLFINICHO/001/2005, 003/2006 and 004/2006) and I.C.'s doctoral grant (SFRH/BD/41192/2007). They also acknowledge FCT for its pluri-annual funding to Research Unit \#531. They wish to thank two anonymous referees who commented on an earlier version of the manuscript, as well as S. Borràs, J. Wiszniewski and all the persons who contributed to this project, with special thanks to the skippers (P. Martins, V. Rosa, R. Bettencourt, N. Serpa, H. Vieira and J. Viveiros), whose dexterity greatly helped sample collection. Sample collection and analysis complied with the current Portuguese laws. Samples were obtained under sampling permits $06 / \mathrm{CN} / 2002,11 / \mathrm{CN} / 2003,3 / \mathrm{CN} / 2004$ and $7 / \mathrm{CN} / 2005$ of the Environment Directorate of the Regional Government of the Azores, and Of. 668/04 Inf 711/04 DAC/DSCN, Credential $n^{0}$ 103-107/2006/CAPT from the Instituto de Conservação da Natureza. 


\section{Literature cited}

Abend AG, Smith TD (1997) Differences in stable isotope ratios of carbon and nitrogen between long-finned pilot whales (Globicephala melas) and their primary prey in the western north Atlantic. ICES Journal of Marine Science 54: 500-503

Aguilar A, Borrell A (1990) Patterns of lipid content and stratification in the blubber of fin whales (Balaenoptera physalus). J Mammal 71: 544-554

Arnould JPY, Nelson MM, Nichols PD, Oosthuizen WH (2005) Variation in the fatty acid composition of blubber in Cape fur seals (Arctocephalus pusillus pusillus) and the implications for dietary interpretation. J Comp Physiol B 175: 285-295

Bandarra NM, Batista I, Nunes ML, Empis JM, Christie WW (1997) Seasonal changes in lipid composition of sardine (Sardina pilchardus). J Food Sci 62 (1): 40-42

Borobia M, Gearing PJ, Simard Y, Gearing JN, Beland P (1995) Blubber fatty acids of finback and humpback whales from the Gulf of St. Lawrence. Mar Biol 122: 341-353

Borrell A, Aguilar A, Tornero V, Sequeira M, Fernandez G, Ahs S (2006) Organochlorine compounds and stable isotopes indicate bottlenose dolphin subpopulation structure around the Iberian Peninsula. Environ Int 32: 516-523

Brown DJ, Boyd IL, Cripps GC, Butler PJ (1999) Fatty acid signature analysis from the milk of Antarctic fur seals and Southern elephant seals from South Georgia: implications for diet determination. Mar Ecol Prog Ser 187: 251-263

Budge SM, Iverson SJ, Koopman HN (2006) Studying trophic ecology in marine ecosystems using fatty acids: a primer on analysis and interpretation. Mar Mamm Sci 22: 759-801

Cañadas A, Sagarminaga R, García-Tiscar S (2002) Cetacean distribution related with depth and slope in the Mediterranean waters off southern Spain. Deep Sea Res 49: 2053-2073

Chou L, Bright AM, Yeh S (1995) Stomach content of dolphins from North Pacific ocean Zool Stud 34: 206-210

Dahl TM, Lydersen C, Kovacs KM, Falk-Petersen S, Sargent J, Gjertz I, Gulliksen B (2000) Fatty acid composition of the blubber in white whales (Delphinapterus leucas). Polar Biol 23: 401-409

Das K, Lepoint G, Loizeau V, Debacker V, Dauby P, Bouquegneau JM (2000) Tuna and dolphin associations in the north-east Atlantic: evidence of different ecological niches from stable isotope and heavy metal measurements. Mar Pollut Bull 40: 102-109

Das K, Lepoint G, Leroy Y, Bouquegneau JM (2003) Marine mammals from the southern North sea: feeding ecology data from $\delta^{13} \mathrm{C}$ and $\delta^{15} \mathrm{~N}$ measurements. Mar Ecol Prog Ser 263: 287298

Dinis A, Cascão I, Alves F, Freitas L, Quérouil S (2008) Comparing the epipelagic diet between short-beaked common dolphin and Atlantic spotted dolphin in two Atlantic oceanic archipelagos 22nd Conference of the European Cetacean Society, Egmond aan Zee, The Netherlands

Evans WE (1994) Common dolphin, white-bellied purpoise Delphinus delphis Linnaeus 1758. In: Ridgway SH, Harrison R (eds) Handbook of marine mammals, vol 5: the first book of dolphins. Academic Press, London, pp 191-224

Falk-Petersen S, Haug T, Nilssen KT, Wold A, Dahl TM (2004) Lipids and trophic linkages in harp seal (Phoca groenlandica) from the eastern Barents Sea. Polar Res 23: 43-50

Freitas L, Alves F, Dinis A, Nóbrega F (2004) Relatório dos resultados científicos. Projecto para a conservação dos cetáceos no Arquipélago da Madeira (Project report).

Gonçalves JM, Barreiros JP, Azevedo JN, Norberto R (1996) Cetaceans stranded in the Azores during 1992-96. Arquipelago 14A: 57-65

Grinnell J (1924) Geography and evolution. Ecology V-3: 225-229 
Guitart R, Silvestre AM, Guerrero X, Mateo R (1999) Comparative study of the fatty acid composition of two marine vertebrates: striped dolphins and loggerhead turtles. Comp Biochem Physiol 124 B: 439-443

Heithaus MR, Dill LM (2002) Food availability and tiger shark predation influence dolphin habitat use. Ecology 83: 480-491

Hicks BD, St Aubin DJ, Geraci JR, Brown WR (1985) Epidermal growth in the bottlenose dolphin, Tursiops truncatus. The Journal of Investigative Dermatology 85: 60-63

Hobson KA, Welch HE (1992) Determination of trophic relationships within a high Arctic marine food web using delta-13C and delta-15N analysis. Mar Ecol Prog Ser 84: 9-18

Hooker SK, Iverson SJ, Ostrom P, Smith SC (2001) Diet of northern bottlenose whales inferred from fatty-acid and stable-isotope analyses of biopsy samples. Can J Zool 79: 1442-1454

Iverson SJ, Arnould JPY, Boyd IL (1997a) Milk fatty acid signatures indicate both major and minor shifts in the diet of lactating Antarctic fur seals. Can J Zool 75: 188-197

Iverson SJ, Frost KJ, Lowry LF (1997b) Fatty acid signatures reveal fine scale structure of foraging distribution of harbor seals and their prey in Prince William Sound, Alaska. Mar Ecol Prog Ser 151: 255-271

Iverson SJ, Field C, Bowen WD, Blanchard W (2004) Quantitative fatty acid signature analysis: a new method of estimating predator diets. Ecol Monogr 74: 211-235

Kirsch PE, Iverson SJ, Bowen WD, Kerr SR, Ackman RG (1998) Dietary effects on the fatty acid signature of whole Atlantic cod (Gadus morhua). Can J Fish Aquat Sci 55: 1378-1386

Kirsch PE, Iverson SJ, Bowen WD (2000) Effect of a low-fat diet on body composition and blubber fatty acids of captive juvenile harp seals (Phoca groenlandica). Physiol Biochem Zool 73: 45-59

Kiszka J, Orémus M, Richard P, Poole MM, Ridoux V (2010a) The use of stable isotope analyses from skin biopsy samples to assess trophic relationships of sympatric delphinids off Moorea (French Polynesia). J Exp Mar Biol Ecol 395: 48-54

Kiszka J, Simon-Bouhet B, Charlier F, Pusineri C, Ridoux V (2010b) Individual and group behavioural reactions of small delphinids to remote biopsy sampling. Animal Welfare 19: 411-417

Kiszka J, Simon-Bouhet B, Martinez L, Pusineri C, Richard P, Ridoux V (2011) Ecological niche segregation within a community of sympatric dolphins around a tropical island. Mar Ecol Prog Ser 433: 273-288

Kleivane L, Espeland O, Ugland KI, Skaare JU (1995) Seasonal variation of organochlorine concentrations in harp seal (Phoca groenlandica). In: Blix AS, Walløe L, Ulltang Ø (eds) Whales, seals, fish and man. Elsevier Science B.V., Amsterdam, pp 599-605

Koopman HN, Iverson SJ, Gaskin DE (1996) Stratification and age-related differences in blubber fatty acids of the male harbour porpoise (Phocoena phocoena). J Comp Physiol B 165: 628-639

Koopman HN, Iverson SJ, Read AJ (2003) High concentrations of isovaleric acid in the fats of odontocetes: Stability in the melon vs. variation and patterns of accumulation in blubber. $\mathrm{J}$ Comp Physiol B 173: 247-261

Kramer JK, Blackadar CB, Zhou J (2002) Evaluation of two GC columns (60 m Supelcowax 10 and $100 \mathrm{~m} \mathrm{CP}$ Sil 88) for analysis of milkfat with emphasis on CLA, 18:1, 18:2 and 18:3 isomers, and short and long-chain fatty acids. Lipids 37: 823-835

Le Duc RG, Perrin WF, Dizon AE (1999) Phylogenetic relationships among the delphinid cetaceans based on full cytochrome $b$ sequences. Mar Mamm Sci 15: 619-648

Lesage V, Hammill MO, Kovacs KM (2001) Marine mammals and the community structure of the Estuary and Gulf of St Lawrence, Canada: evidence from stable isotope analysis. Mar Ecol Prog Ser 210: 203-221 
Lopes XM, de Oliveira Santos MC, da Silva E, Bassoi M, Aguiar dos Santos R (2012) Feeding habits of the Atlantic spotted dolphin, Stenella frontalis, in southeastern Brazil. Braz J Oceanogr 60: 189-198

Mathews EA, Keller S, Weiner DB (1988) A method to collect and process skin biopsies for cell culture from the free-ranging gray whales (Eschrichtius robustus). Mar Mamm Sci 4: 1-12

Meynier L, Pusineri C, Spitz J, Santos MB, Pierce GJ, Ridoux V (2008) Intraspecific dietary variation in the short-beaked common dolphin Delphinus delphis in the Bay of Biscay: importance of fat fish. Mar Ecol Prog Ser 354: 277-287

Nakamura MT, Nara TY (2003) Essential fatty acid synthesis and its regulation in mammals. Prostag Leukotr Ess 68: 145-150

Newland C, Field IC, Nichols PD, Bradshaw CJA, Hindell MA (2009) Blubber fatty acid profiles indicate dietary resource partitioning between adult and juvenile southern elephant seals. Mar Ecol Prog Ser 384: 303-312

Olsen E, Grahl-Nielsen O (2003) Blubber fatty acids of minke whales: stratification, population identification and relation to diet. Mar Biol 142: 13-24

Özyurt G, Duysak Ö, Akamca E, Tureli C (2006) Seasonal changes of fatty acids of cuttlefish Sepia officinalis L. (Mollusca: Cephalopoda) in the north eastern Mediterranean sea. Food Chem 95: 382-385

Park Y, Albright KJ, Cai ZY, Pariza MW (2001) Comparison of methylation procedures for conjugated linoleic acid and artefact formation by commercial (trimethylsilyl) diazomethane. J Agric Food Chem 49: 1158-1164

Pauly D, Trites AW, Capuli E, Christensen V (1998) Diet composition and trophic levels of marine mammals. ICES Journal of Marine Science 55: 467-481

Perrin WF, Caldwell DK, Caldwell MC (1994) Atlantic spotted dolphin Stenella frontalis (G. Cuvier, 1829). In: Ridgway SH, Harrison R (eds) Handbook of marine mammals, vol 5: the first book of dolphins. Academic Press, London, pp 173-190

Phillips KL, Nichols PD, Jackson GD (2002) Lipid and fatty acid composition of the mantle and digestive gland of four Southern Ocean squid species: implications for food-web studies. Antarct Sci 14: 212-220

Pianka ER (1974) Niche overlap and diffuse competition. Proc Natl Acad Sci USA 71: 2141-2145

Praca E, Gannier A (2008) Ecological niches of three teuthophageous odontocetes in the northwestern Mediterranean Sea. Ocean Sci 4: 49-59

Praca E, Laran S, Lepoint G, Thomé J-P, Quetglas A, Belcari P, Sartor P, Dhermain F, Ody D, Tapie N, Budzinski H, Das K (2011) Toothed whales in the northwestern Mediterranean: Insight into their feeding ecology using chemical tracers. Mar Pollut Bull: 1058-1065

Pusineri C, Magnin V, Meynier L, Spitz J, Hassani S, Ridoux V (2007) Food and feeding ecology of the common dolphin (Delphinus delphis) in the oceanic Northeast Atlantic and comparison with its diet in neritic areas. Mar Mamm Sci 23: 30-47

Quérouil S, Silva MA, Cascão I, Magalhães S, Seabra MI, Machete MA, Santos RS (2008) Why do dolphins form mixed-species associations in the Azores? Ethology 114: 1183-1194

Quérouil S, Freitas L, Cascão I, Alves F, Dinis A, Almeida JR, Prieto R, Borràs S, Matos JA, Mendonça D, Santos RS (2010a) Molecular insight on the population structure of common and spotted dolphins inhabiting the pelagic waters of the Northeast Atlantic. Mar Biol 157: $2567-2580$

Quérouil S, Freitas L, Dinis A, Alves F, Cascão I, Prieto R, Silva MA, Magalhães S, Matos JA, Santos RS (2010b) Sex bias in biopsy samples collected from free-ranging dolphins. Eur J Wildl Res 56: 151-158

Roughgarden J (1976) Resource partitioning among competing species: a coevolutionary approach. Theor Popul Biol 9: 388-424 
Saito H, Murata M (1998) Origin of the monoene fats in the lipid of midwater fishes: relationship between the lipids of myctophids and those of their prey. Mar Ecol Prog Ser 168: 21-33

Samuel AM, Worthy GAJ (2004) Variability in fatty acid composition of bottlenose dolphin (Tursiops truncatus) blubber as a function of body site, season, and reproductive state. Can J Zool 82: 1933-1942

Santos-Reis M, Mathias ML (1996) The historical and recent distribution and status of mammals in Portugal. Hystrix 8: 75-89

Silva MA (1999) Diet of common dolphins, Delphinus delphis, off the Portuguese continental coast. J Mar Biol Assoc UK 79: 531-540

Silva MA, Prieto R, Magalhães S, Cabecinhas R, Cruz A, Gonçalves JM, Santos RS (2003) Occurrence and distribution of cetaceans in the waters around the Azores (Portugal), Summer and Autumn 1999-2000. Aquat Mammal 29: 77-83

Smith HR, Worthy GAJ (2006) Stratification and intra- and inter-specific differences in fatty acid composition of common dolphin (Delphinus sp.) blubber: Implications for dietary analysis. Comp Biochem Physiol B 143: 486-499

Smith RJ, Hobson KA, Koopman HN, Lavigne DM (1996) Distinguishing between populations of fresh- and salt-water harbour seals (Phoca vitulina) using stable-isotope ratios and fatty acid probes. Can J Fish Aquat Sci 53: 272-279

St Aubin DJ, Smith TG, Geraci JR (1990) Seasonal epidermal molt in beluga whales, Delphinapterus leucas. Revue canadienne de zoologie 8: 359-367

Steiner L, Silva MA, Zereba J, Leal MJ (2007) Bryde's Whales, Balaenoptera edeni, observed in the Azores: a new species record for the region. J Mar Biol Assoc UK, Biodiversity Records: 6p.

Strandberg U, Käkelä A, Lydersen C, Kovacs KM, Grahl-Nielsen O, Hyvärinen H, Käkelä R (2008) Stratification, composition, and function of marine mammal blubber: The ecology of fatty acids in marine mammals. Physiol Biochem Zool 81: 473-485

Thiemann GW, Iverson SJ, Stirling I (2008) Variation in blubber fatty acid composition among marine mammals in the Canadian Arctic. Mar Mamm Sci 24: 91-111

Wade PR, Angliss R (1997) Guidelines for Assessing Marine Mammal Stocks: Report of the GAMMS Workshop, April 3-5, 1996, Seattle, Washington. Office of Protected Resources, National Marine Fisheries Service, Silver Spring, Maryland

Walton M, Pomeroy P (2003) Using blubber fatty acid profiles to detect inter-annual variations in the diet of grey seals Halichoerus grypus. Mar Ecol Prog Ser 248: 257-266

Walton MJ, Silva MA, Magalhães SM, Prieto R, Santos RS (2007) Using blubber biopsies to provide ecological information about bottlenose dolphins (Tursiops truncatus) around the Azores. J Mar Biol Assoc UK 87: 223-230

Wang C, Harris WS, Chung M, Lichtenstein AH, Balk EM, Kupelnick B, Jordan HS, Lau J (2006) n-3 Fatty acids from fish or fish-oil supplements, but not $\alpha$-linolenic acid, benefit cardiovascular disease outcomes in primary- and secondary-prevention studies: a systematic review. Am J Clin Nutr 84: 5-17

Wheatley KE, Nichols PD, Hindell MA, Harcourt RG, Bradshaw CJA (2007) Temporal variation in the vertical stratification of blubber fatty acids alters diet predictions for lactating Weddell seals. J Exp Mar Biol Ecol 352: 103-113

Williams G, Crawford MA, Perrin WF (1987) Comparison of the fatty acid component in structural lipids from dolphins, zebra and giraffe: possible evolutionary implications. J Zool 213: 673-684

Young DD, Cockcroft VG (1994) Diet of common dolphins (Delphinus delphis) off the south-east coast of southern Africa: Opportunism or specialization? J Zool 234: 41-53 
Table 1: Number of samples analysed per species, archipelago and method.

\begin{tabular}{llllllll}
\hline & \multicolumn{3}{c}{ D. delphis } & \multicolumn{3}{c}{ S. frontalis } \\
\hline & Azores & Madeira & All & Azores & Madeira & All \\
\hline Sampling & & Jun.-Sep. & Jan.-Jun. & & Jul.-Aug. & Jun.-Nov. \\
period & & $2005-6$ & $2005-6$ & & $2005-6$ & $2005^{\text {a }}$ & \\
\hline Fatty acids & males & 12 & 18 & 30 & 10 & 16 & 26 \\
& females & 10 & 4 & 14 & 12 & 4 & 16 \\
& total & 22 & 22 & 44 & 22 & 20 & 42 \\
\hline Stable & males & 30 & 23 & 53 & 27 & 14 & 41 \\
isotopes & & & & & & & \\
& females & 25 & 5 & 30 & 17 & 9 & 26 \\
& total & 55 & 28 & 83 & 44 & 23 & 67 \\
\hline
\end{tabular}

${ }^{\mathrm{a}}$ one sample collected in November 2004

Table 3: Effect (p-value) of archipelagos, species, sex, and their interaction on the FA profiles of D. delphis and $S$. frontalis samples, based on all fatty acids (All FA; multivariate ANOVA, d.f. = 20), saturated (SFA), monounsaturated (MUFA), polyunsaturated (PUFA), and n-3 and n-6 polyunsaturated fatty acids (univariate ANOVA, d.f. $=1$ ). Significant values $(\mathrm{p}<0.05)$ are in bold.

\begin{tabular}{|c|c|c|c|c|c|c|}
\hline & All FA & SFA & MUFA & PUFA & $n-3$ & $n-6$ \\
\hline \multicolumn{7}{|l|}{ D. delphis } \\
\hline archipelago & $<0.0001$ & 0.009 & 0.005 & $<0.0001$ & 0.005 & $<0.0001$ \\
\hline $\operatorname{sex}$ & 0.006 & 0.592 & 0.448 & 0.003 & 0.268 & 0.071 \\
\hline archipelago x sex & 0.002 & 0.795 & 0.275 & 0.232 & 0.678 & 0.871 \\
\hline \multicolumn{7}{|l|}{ S. frontalis } \\
\hline archipelago & 0.008 & 0.760 & 0.308 & 0.361 & 0.434 & 0.013 \\
\hline sex & 0.167 & 0.306 & 0.190 & 0.226 & 0.229 & 0.294 \\
\hline archipelago $\mathrm{x}$ sex & 0.857 & 0.394 & 0.697 & 0.998 & 0.996 & 0.970 \\
\hline \multicolumn{7}{|l|}{ Azores } \\
\hline species & $<0.0001$ & 0.145 & 0.026 & 0.011 & 0.014 & 0.004 \\
\hline sex & 0.101 & 0.578 & 0.740 & 0.656 & 0.697 & 0.309 \\
\hline species $x$ sex & 0.226 & 0.111 & 0.027 & 0.060 & 0.067 & 0.042 \\
\hline
\end{tabular}


Table 2: Fatty acid profiles (mean \pm standard deviation, in \% total FA) of D. delphis and S. frontalis blubber samples obtained in the Azores and Madeira, averaged per sex.

\begin{tabular}{|c|c|c|c|c|c|c|c|c|c|c|c|c|}
\hline \multirow[b]{3}{*}{ Fatty Acids } & \multicolumn{6}{|l|}{ D. delphis } & \multicolumn{6}{|l|}{ S. frontalis } \\
\hline & Azores & & & Madeira & & & Azores & & & Madeira & & \\
\hline & $\begin{array}{l}\text { Males } \\
(n=12)\end{array}$ & $\begin{array}{l}\begin{array}{l}\text { Females } \\
(n=10)\end{array} \\
\end{array}$ & $\begin{array}{l}\text { Total } \\
(\mathrm{n}=22)\end{array}$ & $\begin{array}{l}\text { Males } \\
(\mathrm{n}=18)\end{array}$ & $\begin{array}{l}\text { Females } \\
(n=4)\end{array}$ & $\begin{array}{l}\text { Total } \\
(\mathrm{n}=22)\end{array}$ & $\begin{array}{l}\text { Males } \\
(\mathrm{n}=10)\end{array}$ & $\begin{array}{l}\text { Females } \\
(n=12)\end{array}$ & $\begin{array}{l}\text { Total } \\
(\mathrm{n}=22)\end{array}$ & $\begin{array}{l}\text { Males } \\
(n=16)\end{array}$ & $\begin{array}{l}\text { Females } \\
(n=4)\end{array}$ & $\begin{array}{l}\text { Total } \\
(\mathrm{n}=\mathbf{2 0})\end{array}$ \\
\hline 14:0 & $4.39 \pm 0.44$ & $4.06 \pm 0.76$ & $4.24 \pm 0.61$ & $3.48 \pm 0.93$ & $3.31 \pm 0.88$ & $3.44 \pm 0.86$ & $3.81 \pm 0.39$ & $4.11 \pm 0.34$ & $3.97 \pm 0.38$ & $3.61 \pm 0.32$ & $3.45 \pm 0.23$ & $3.58 \pm 0.31$ \\
\hline $14: 0$ isobr. & $0.64 \pm 0.17$ & $0.71 \pm 0.20$ & $0.67 \pm 0.19$ & $0.72 \pm 0.22$ & $1.04 \pm 0.50$ & $0.79 \pm 0.30$ & $0.49 \pm 0.15$ & $0.45 \pm 0.10$ & $0.47 \pm 0.12$ & $0.42 \pm 0.17$ & $0.45 \pm 0.13$ & $0.42 \pm 0.16$ \\
\hline 15:0 & $0.66 \pm 0.06$ & $0.63 \pm 0.10$ & $0.65 \pm 0.08$ & $0.50 \pm 0.10$ & $0.52 \pm 0.14$ & $0.51 \pm 0.10$ & $0.67 \pm 0.05$ & $0.69 \pm 0.04$ & $0.68 \pm 0.05$ & $0.66 \pm 0.06$ & $0.63 \pm 0.07$ & $0.66 \pm 0.06$ \\
\hline 16:0 & $6.64 \pm 2.02$ & $6.20 \pm 2.38$ & $6.44 \pm 2.15$ & $4.81 \pm 2.17$ & $4.40 \pm 1.97$ & $4.67 \pm 2.00$ & $6.95 \pm 1.76$ & $8.35 \pm 1.44$ & $7.71 \pm 1.71$ & $7.71 \pm 2.42$ & $8.03 \pm 1.12$ & $7.77 \pm 2.20$ \\
\hline 17:0 & $0.88 \pm 0.21$ & $0.89 \pm 0.21$ & $0.89 \pm 0.20$ & $0.94 \pm 0.09$ & $0.98 \pm 0.12$ & $0.95 \pm 0.09$ & $1.14 \pm 0.09$ & $1.12 \pm 0.10$ & $1.13 \pm 0.09$ & $1.10 \pm 0.11$ & $1.03 \pm 0.16$ & $1.09 \pm 0.12$ \\
\hline 18:0 & $1.98 \pm 0.65$ & $1.80 \pm 0.64$ & $1.90 \pm 0.64$ & $1.52 \pm 0.60$ & $1.34 \pm 0.44$ & $1.47 \pm 0.54$ & $2.00 \pm 0.67$ & $2.14 \pm 0.75$ & $2.08 \pm 0.70$ & $2.09 \pm 0.80$ & $2.16 \pm 0.45$ & $2.11 \pm 0.73$ \\
\hline$\Sigma$ SFA $^{\mathrm{a}}$ & $15.18 \pm 2.65$ & $14.30 \pm 3.45$ & $14.78 \pm 3.00$ & $11.97 \pm 3.42$ & $11.58 \pm 3.17$ & $11.83 \pm 3.15$ & $15.06 \pm 2.64$ & $16.86 \pm 1.97$ & $16.05 \pm 2.46$ & $15.59 \pm 3.17$ & $15.75 \pm 1.08$ & $15.62 \pm 2.94$ \\
\hline $14: 1 n-5$ & $2.06 \pm 1.28$ & $2.26 \pm 0.96$ & $2.15 \pm 1.12$ & $2.87 \pm 1.22$ & $3.39 \pm 1.08$ & $3.01 \pm 1.14$ & $1.81 \pm 0.91$ & $1.19 \pm 0.43$ & $1.47 \pm 0.74$ & $1.63 \pm 0.87$ & $1.23 \pm 0.46$ & $1.55 \pm 0.81$ \\
\hline 16:1n-9 & $1.45 \pm 0.57$ & $1.61 \pm 0.53$ & $1.51 \pm 0.55$ & $2.03 \pm 0.88$ & $2.96 \pm 0.59$ & $2.26 \pm 0.86$ & $1.29 \pm 0.84$ & $1.26 \pm 0.22$ & $1.25 \pm 0.32$ & $1.46 \pm 0.78$ & $1.21 \pm 0.42$ & $1.41 \pm 0.70$ \\
\hline $16: 1 n-7$ & $15.04 \pm 4.38$ & $17.04 \pm 4.64$ & $15.95 \pm 4.51$ & $17.76 \pm 4.68$ & $17.96 \pm 2.15$ & $18.22 \pm 4.26$ & $16.03 \pm 4.96$ & $12.88 \pm 2.54$ & $14.31 \pm 4.06$ & $15.06 \pm 4.10$ & $13.79 \pm 2.37$ & $14.81 \pm 3.80$ \\
\hline 18:1n-9 & $23.70 \pm 1.26$ & $25.77 \pm 2.29$ & $24.64 \pm 2.05$ & $27.18 \pm 2.09$ & $27.09 \pm 1.60$ & $27.54 \pm 2.24$ & $29.29 \pm 1.64$ & $29.13 \pm 1.70$ & $29.21 \pm 1.63$ & $30.21 \pm 1.72$ & $30.12 \pm 1.98$ & $30.20 \pm 1.72$ \\
\hline $18: 1 n-7$ & $2.14 \pm 0.19$ & $1.93 \pm 0.69$ & $2.04 \pm 0.48$ & $2.02 \pm 0.15$ & $2.15 \pm 0.21$ & $2.06 \pm 0.17$ & $1.91 \pm 0.26$ & $1.95 \pm 0.28$ & $1.93 \pm 0.26$ & $2.13 \pm 0.25$ & $2.18 \pm 0.28$ & $2.14 \pm 0.25$ \\
\hline 20:1n-9 & $1.51 \pm 0.32$ & $2.21 \pm 0.97$ & $1.83 \pm 0.77$ & $2.82 \pm 1.37$ & $1.28 \pm 1.39$ & $2.52 \pm 1.41$ & $3.46 \pm 1.08$ & $3.98 \pm 0.96$ & $3.74 \pm 1.03$ & $4.54 \pm 1.36$ & $4.65 \pm 1.22$ & $4.56 \pm 1.30$ \\
\hline$\Sigma$ MUFA $^{\mathrm{b}}$ & $45.78 \pm 6.07$ & $50.34 \pm 6.58$ & $47.85 \pm 6.57$ & $54.56 \pm 7.72$ & $54.83 \pm 4.86$ & $55.51 \pm 7.38$ & $53.53 \pm 6.08$ & $49.87 \pm 3.68$ & $51.91 \pm 5.28$ & $54.93 \pm 6.30$ & $53.17 \pm 3.27$ & $54.65 \pm 5.95$ \\
\hline $16: 3 n-3$ & $1.15 \pm 0.14$ & $1.27 \pm 0.19$ & $1.20 \pm 0.17$ & $1.37 \pm 0.21$ & $1.37 \pm 0.09$ & $1.39 \pm 0.19$ & $1.13 \pm 0.36$ & $1.10 \pm 0.12$ & $1.11 \pm 0.25$ & $1.23 \pm 0.17$ & $1.17 \pm 0.14$ & $1.22 \pm 0.17$ \\
\hline $18: 2 n-6$ & $1.75 \pm 0.06$ & $1.67 \pm 0.08$ & $1.71 \pm 0.08$ & $1.64 \pm 0.09$ & $1.63 \pm 0.10$ & $1.64 \pm 0.09$ & $1.47 \pm 0.06$ & $1.45 \pm 0.09$ & $1.46 \pm 0.07$ & $1.34 \pm 0.12$ & $1.31 \pm 0.10$ & $1.34 \pm 0.11$ \\
\hline $18: 3 n-3$ & $0.59 \pm 0.09$ & $0.68 \pm 0.10$ & $0.63 \pm 0.10$ & $0.83 \pm 0.06$ & $0.78 \pm 0.03$ & $0.82 \pm 0.05$ & $0.53 \pm 0.04$ & $0.51 \pm 0.06$ & $0.52 \pm 0.06$ & $0.46 \pm 0.14$ & $0.45 \pm 0.16$ & $0.46 \pm 0.14$ \\
\hline $20: 4 n-6$ & $1.07 \pm 0.17$ & $1.12 \pm 0.21$ & $1.09 \pm 0.18$ & $0.90 \pm 0.28$ & $0.67 \pm 0.36$ & $0.80 \pm 0.34$ & $0.98 \pm 0.05$ & $0.91 \pm 0.10$ & $0.94 \pm 0.08$ & $0.89 \pm 0.14$ & $0.88 \pm 0.04$ & $0.89 \pm 0.13$ \\
\hline $20: 4 n-3$ & $0.67 \pm 0.10$ & $0.72 \pm 0.09$ & $0.69 \pm 0.10$ & $0.86 \pm 0.21$ & $0.75 \pm 0.10$ & $0.82 \pm 0.19$ & $0.56 \pm 0.09$ & $0.59 \pm 0.06$ & $0.58 \pm 0.07$ & $0.51 \pm 0.10$ & $0.53 \pm 0.08$ & $0.51 \pm 0.09$ \\
\hline 20:5n-3 (EPA) & $2.72 \pm 0.76$ & $2.91 \pm 0.55$ & $2.80 \pm 0.67$ & $2.69 \pm 0.75$ & $2.70 \pm 0.66$ & $2.61 \pm 0.74$ & $1.73 \pm 0.40$ & $1.71 \pm 0.44$ & $1.72 \pm 0.41$ & $1.70 \pm 0.40$ & $1.88 \pm 0.20$ & $1.73 \pm 0.37$ \\
\hline $22: 5 n-6$ & $0.93 \pm 0.34$ & $0.65 \pm 0.26$ & $0.80 \pm 0.33$ & $0.52 \pm 0.17$ & $0.39 \pm 0.10$ & $0.47 \pm 0.18$ & $0.80 \pm 0.30$ & $0.98 \pm \pm 0.20$ & $0.90 \pm 0.26$ & $0.74 \pm 0.26$ & $0.89 \pm 0.13$ & $0.77 \pm 0.24$ \\
\hline 22:5n-3 (DPA) & $4.09 \pm 1.30$ & $3.02 \pm 1.10$ & $3.61 \pm 1.31$ & $2.71 \pm 1.27$ & $1.62 \pm 0.48$ & $2.37 \pm 1.23$ & $3.18 \pm 1.14$ & $3.26 \pm 0.67$ & $3.22 \pm 0.89$ & $2.74 \pm 1.00$ & $2.86 \pm 0.70$ & $2.76 \pm 0.94$ \\
\hline 22:6n-3 (DHA) & $14.43 \pm 3.12$ & $12.36 \pm 3.35$ & $13.49 \pm 3.32$ & $10.22 \pm 4.04$ & $9.32 \pm 3.26$ & $9.54 \pm 3.98$ & $11.25 \pm 3.16$ & $12.97 \pm 2.17$ & $12.19 \pm 2.74$ & $10.61 \pm 3.61$ & $12.11 \pm 1.56$ & $10.91 \pm 3.33$ \\
\hline$\Sigma$ PUFA $^{\mathrm{c}}$ & $27.40 \pm 4.38$ & $24.39 \pm 4.55$ & $26.03 \pm 4.61$ & $21.73 \pm 5.88$ & $19.23 \pm 4.57$ & $20.45 \pm 5.91$ & $21.62 \pm 4.77$ & $23.49 \pm 2.77$ & $22.64 \pm 3.88$ & $20.22 \pm 4.95$ & $22.08 \pm 2.52$ & $20.59 \pm 4.72$ \\
\hline$\Sigma$ n-3 PUFA & $23.65 \pm 4.11$ & $20.95 \pm 4.27$ & $22.43 \pm 4.31$ & $17.77 \pm 5.95$ & $16.54 \pm 4.37$ & $17.55 \pm 5.61$ & $18.37 \pm 4.48$ & $20.14 \pm 2.79$ & $19.34 \pm 3.67$ & $17.24 \pm 4.85$ & $18.9 \pm 2.47$ & $17.59 \pm 4.48$ \\
\hline$\Sigma$ n-6 PUFA & $3.75 \pm 0.40$ & $3.44 \pm 0.33$ & $3.61 \pm 0.39$ & $2.95 \pm 0.51$ & $2.69 \pm 0.38$ & $2.90 \pm 0.49$ & $3.24 \pm 0.31$ & $3.35 \pm 0.23$ & $3.30 \pm 0.27$ & $2.98 \pm 0.34$ & $3.09 \pm 0.09$ & $3.00 \pm 0.31$ \\
\hline Others $(<0.5 \%)^{\mathrm{d}}$ & $6.94 \pm 0.78$ & $6.35 \pm 1.04$ & $6.67 \pm 0.94$ & $6.68 \pm 1.39$ & $7.69 \pm 2.14$ & $6.73 \pm 1.56$ & $5.80 \pm 0.63$ & $6.19 \pm 0.63$ & $6.01 \pm 0.66$ & $5.75 \pm 0.72$ & $5.69 \pm 0.45$ & $5.74 \pm 0.68$ \\
\hline
\end{tabular}

${ }^{\mathrm{a}}$ SFA saturated fatty acids; ${ }^{\mathrm{b}}$ MUFA monounsaturated fatty acids; ${ }^{\mathrm{c}}$ PUFA polyunsaturated fatty acids;

${ }^{\mathrm{d}}$ Others $(<0.5 \%)$ : all other components observed at less than $0.5 \%$ : 12:0, 13:0, 14:1n-7, 15:1, 16:0 isobr, 16:2n $4,16: 0$ anteiso, phytanic acid, 17:1, 16:4n-3, 18:1n-5, 18:3n-6, 19:0, 18:4n-3, 20:0, $20: 1 n-7,20: 2 n-6,20: 3 n-3,22: 0,22: 1 n-11,22: 1 n-9,22: 4 n-6,22: 4 n-3,24: 1 n-9$. 
Table 4: Discriminatory variables identified by the discriminant function analyses performed between archipelagos within each species, and between species within the Azores (Wilk's $\lambda$ value and significance).

\begin{tabular}{|c|c|c|c|}
\hline & FA & Wilk's $\lambda$ & $\mathrm{p}$ \\
\hline \multicolumn{4}{|c|}{ Between archipelagos } \\
\hline \multirow[t]{2}{*}{ D. delphis } & $18: 3 n-3$ (ALA) & 0.788 & $<0.0001$ \\
\hline & $20: 4 n-6$ & 0.445 & 0.001 \\
\hline \multirow[t]{3}{*}{ S. frontalis } & $20: \ln -9$ & 0.762 & $<0.0001$ \\
\hline & $20: 4 n-3$ & 0.877 & $<0.0001$ \\
\hline & $20: 5 n-3$ (EPA) & 0.704 & 0.0002 \\
\hline \multicolumn{4}{|c|}{ Between species } \\
\hline \multirow[t]{5}{*}{ Azores } & 14:0 isobr & 0.155 & $<0.0001$ \\
\hline & $15: 0$ & 0.145 & 0.0002 \\
\hline & $18: \ln -7$ & 0.154 & $<0.0001$ \\
\hline & $18: 2 n-6$ & 0.170 & $<0.0001$ \\
\hline & $22: 6 n-3(D H A)$ & 0.170 & $<0.0001$ \\
\hline
\end{tabular}

Table 5: Summary of results of fatty acid, carbon and nitrogen isotope analyses: comparison between archipelagos within each species, and between species within the Azores, with indication of main periods of occurrence and sampling $(\neq$ : significant differences between archipelagos or species, NS: no significant differences observed).

\begin{tabular}{lllllc}
\hline & D. delphis & & S. frontalis & & $\begin{array}{l}\text { D. delphis / } \\
\text { S. frontalis }\end{array}$ \\
\hline Archipelago & Azores & Madeira & Azores & Madeira & Azores \\
\hline Main period of occurrence & All year & Jan.-Jun. & Jun.-Sep. & May-Feb. & \\
\hline Main sampling period & Jun.-Sep. & Feb.-Jun. & Jul.-Aug. & Jun.-Oct. & \\
\hline $\begin{array}{l}\text { Fatty acids } \\
\text { diet, habitat, metabolism }\end{array}$ & $\neq$ & & $\neq$ & $\neq$ \\
$\begin{array}{l}\text { Carbon isotopes } \\
\text { foraging habitat / area } \\
\begin{array}{l}\text { Nitrogen isotopes } \\
\text { trophic level }\end{array}\end{array}$ & $\neq$ & & $\neq$ & $\mathrm{NS}$ \\
\hline
\end{tabular}


Figure 1. Map showing the location of the Azores and Madeira in the North Atlantic Ocean.

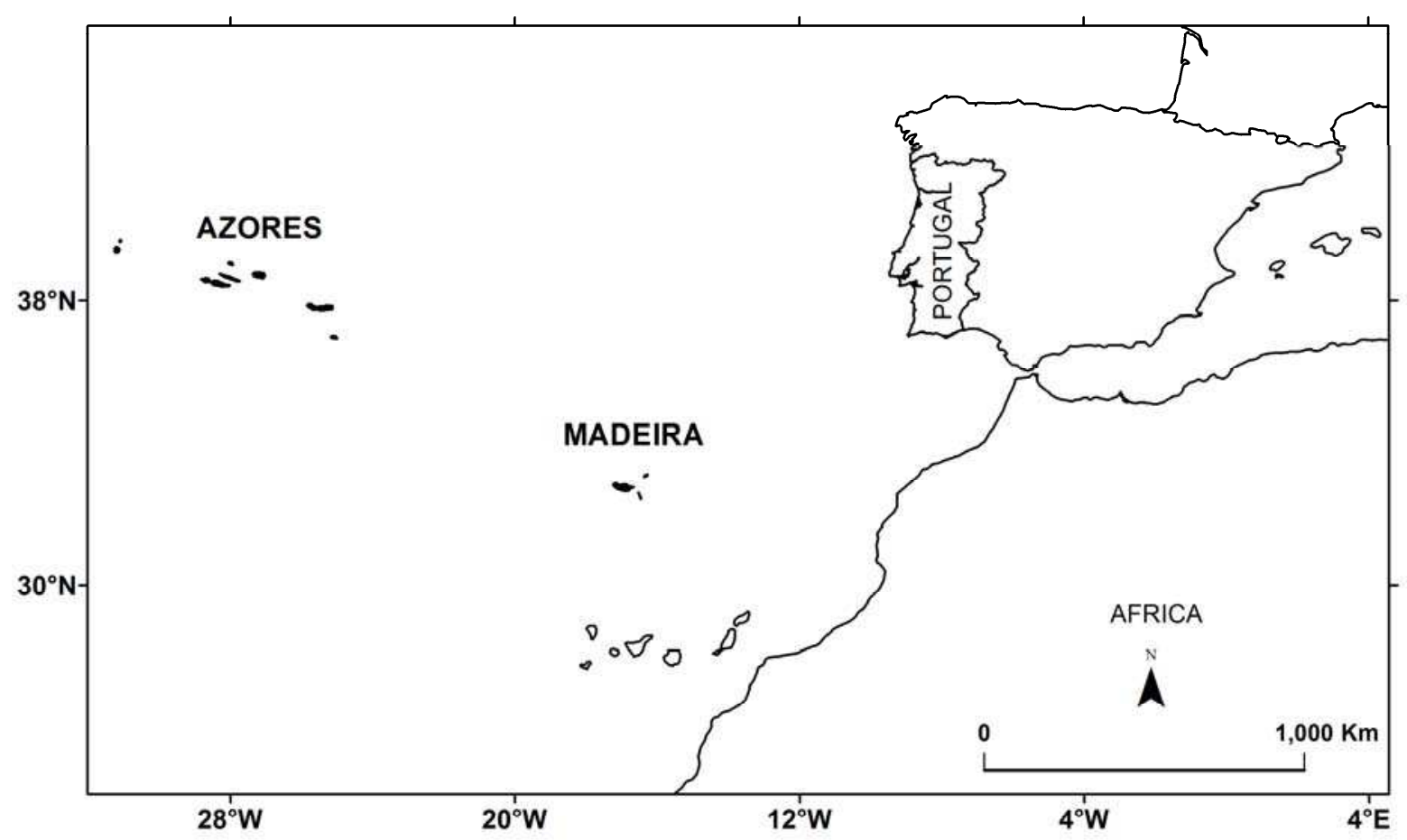


Figure 2. Scatter plot of the first two principal components of the PCA comparing blubber FA proportions of D. delphis samples from the Azores (Az; open symbols) and Madeira (Md; plain symbols). Males (M) are represented by triangles and females (F) by circles. The percentage of variance explained by each PC is indicated between brackets along the axes. PC1 was negatively correlated to FA 22:5n-3 (contribution: $\mathrm{c}=0.085$ ), and PC2 was positively correlated to FA 18:2n$6(\mathrm{c}=0.092)$ and negatively to FA $18: 3 n-3(\mathrm{c}=0.120)$.

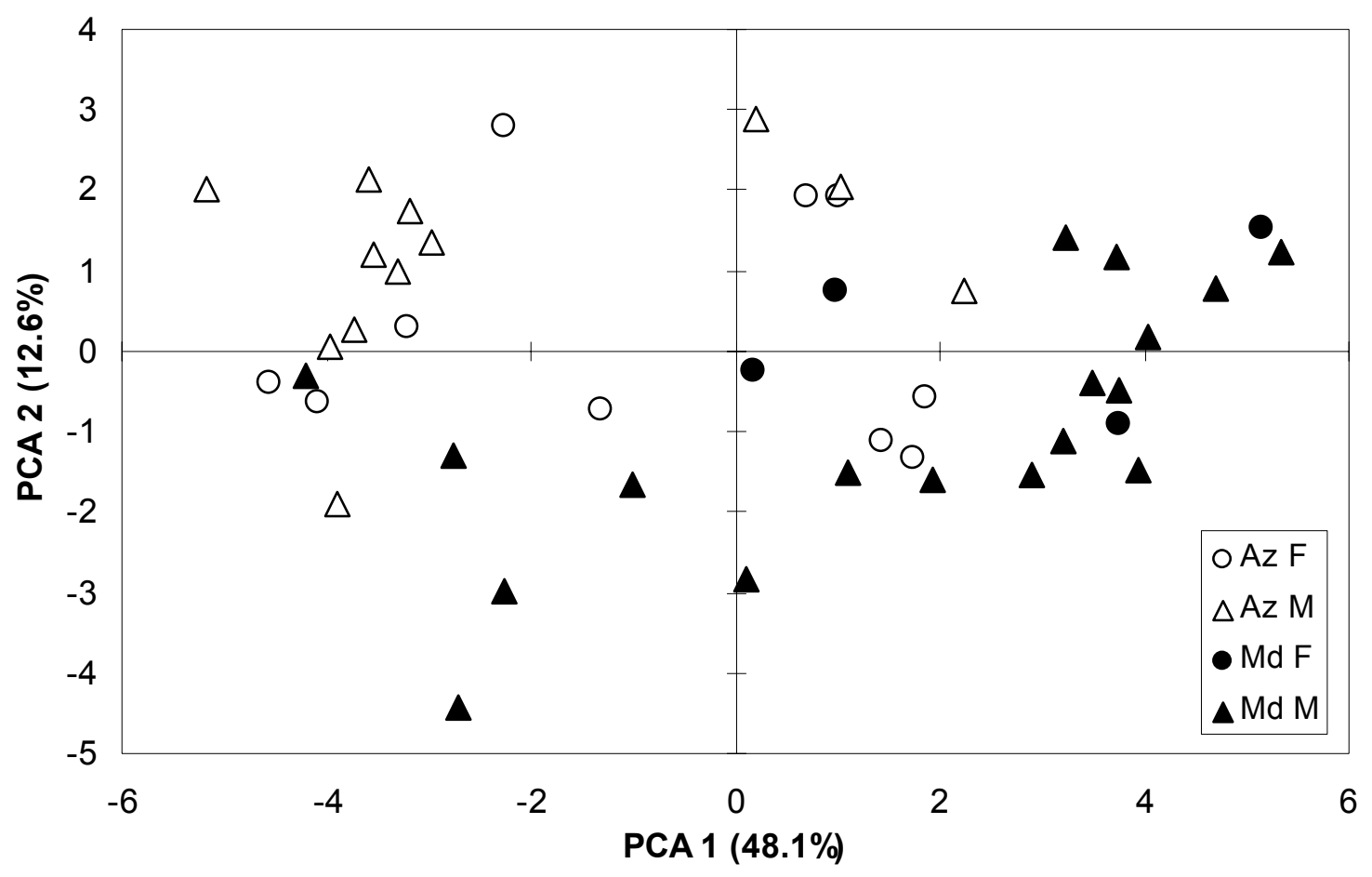


Figure 3. Scatter plot of the first two principal components of the PCA comparing blubber FA proportions of $S$. frontalis samples from the Azores (Az; open symbols) and Madeira (Md; plain symbols). Males (M) are represented by triangles and females (F) by circles. The percentage of variance explained by each PC is indicated between brackets along the axes. PC1 was positively correlated to FA $14: 1 \mathrm{n}-5(\mathrm{c}=0.108)$ and $16: 1 \mathrm{n}-7(\mathrm{c}=0.104)$ and PC2 was positively correlated to FA 18:1n-7 $(c=0.164)$ and 20:1n-9 $(c=0.108)$, and negatively to FA 18:2n-6 $(c=0.210)$.

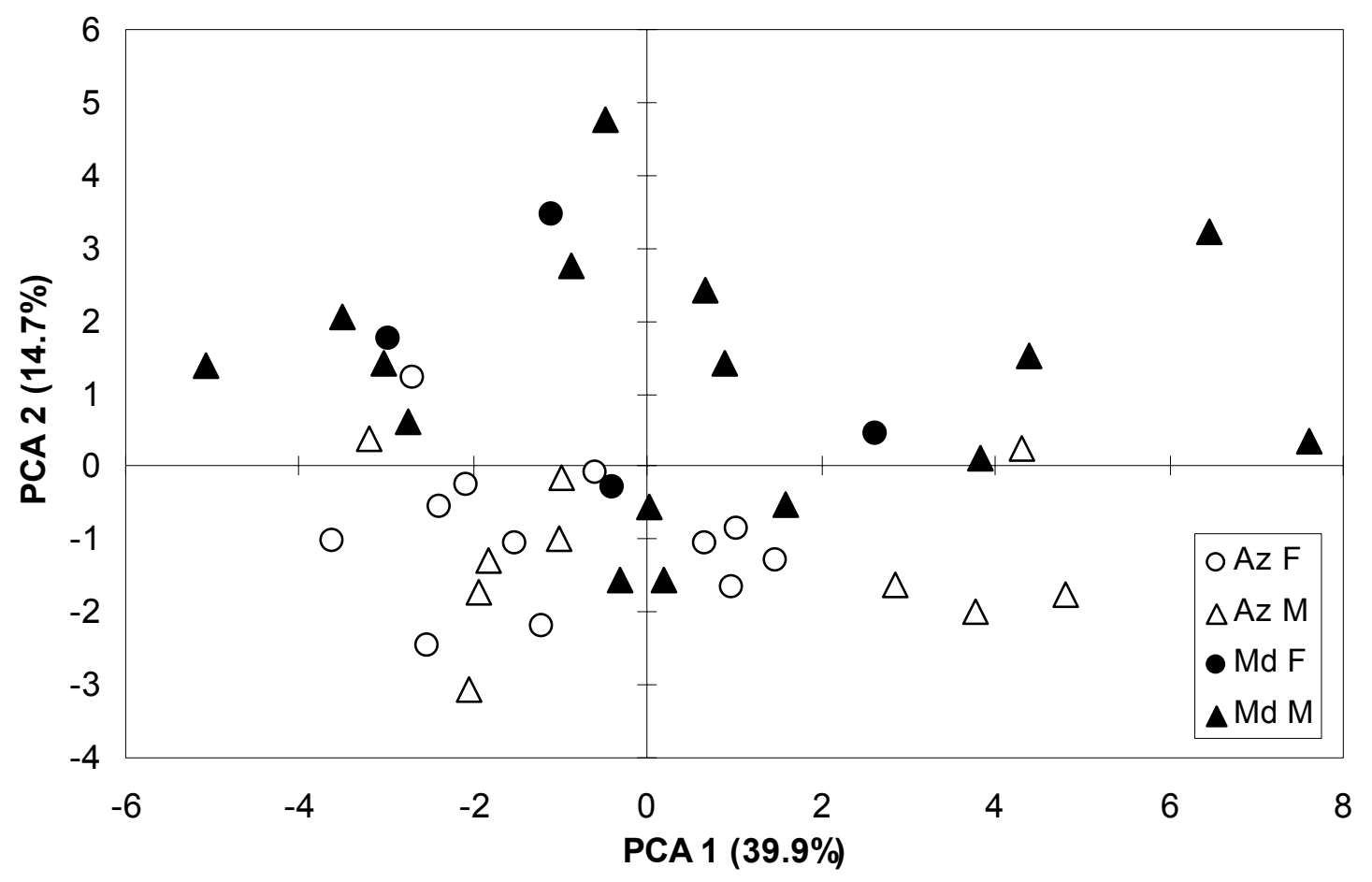


Figure 4. Scatter plot of the first two principal components of the PCA comparing blubber FA proportions of $D$. delphis (Dd; open symbols) and $S$. frontalis (Sf; plain symbols) samples from the Azores. Males (M) are represented by triangles and females (F) by circles. The percentage of variance explained by each PC is indicated between brackets along the axes. PC1 was positively correlated to FA $14: 1 \mathrm{n}-5(\mathrm{c}=0.106)$ and $16: 1 \mathrm{n}-7(\mathrm{c}=0.101)$ and PC2 was positively correlated to FA $18: 1 n-9(c=0.175)$ and negatively to FA $18: 2 n-6(c=0.102)$ and $20: 5 n-3(c=0.106)$.

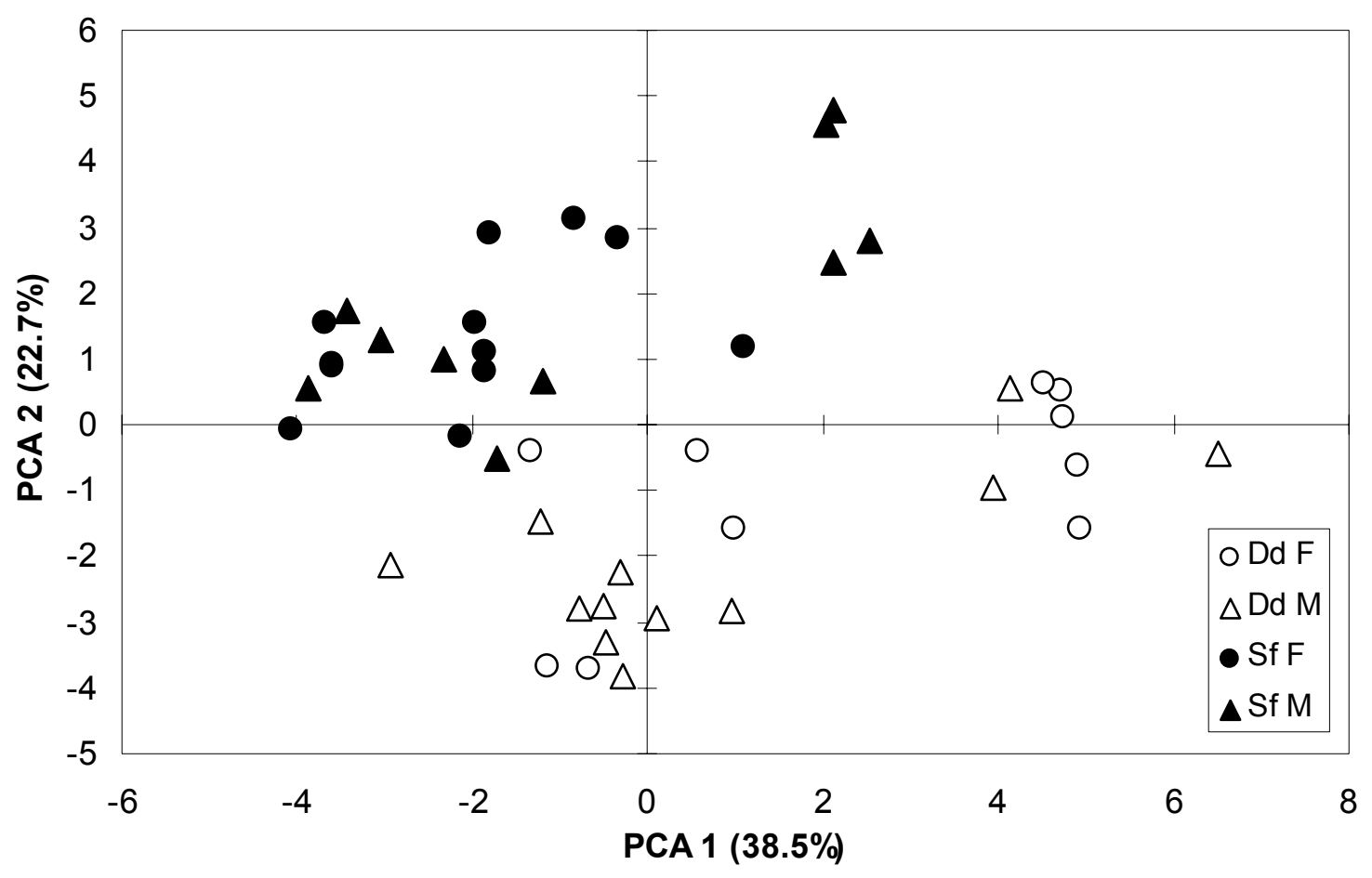


Figure 5. Stable isotopes ratios $\left(\delta^{13} \mathrm{C}\right.$ and $\delta^{15} \mathrm{~N}$ in \%o average values and standard deviations) in common dolphin (grey symbols) and spotted dolphin (black symbols) samples from Madeira (circles) and the Azores (triangles).

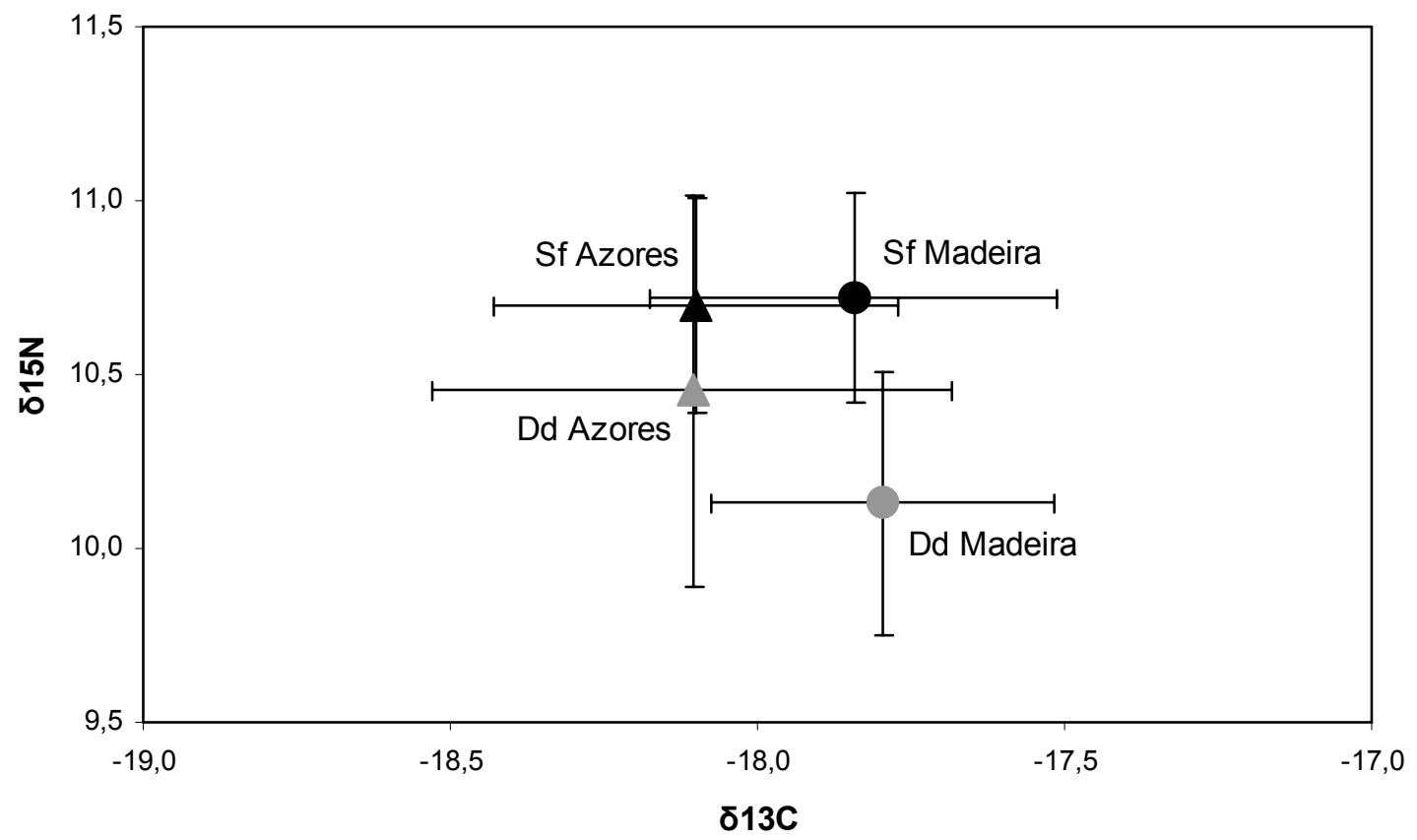

